\title{
Comparing \\ Mulches, \\ Herbicides, and \\ Cultivation as \\ Orchard \\ Groundcover \\ Management Systems
}

\author{
I.A. Merwin', \\ D.A. Rosenberger ${ }^{2}$, \\ C.A. .Engle ${ }^{2}$, D.L. Rist ${ }^{2}$, and \\ M. Fargione ${ }^{2}$
}

Additional index words. Malus
domestics, Microtus spp., low-input
sustainable agriculture, weed control,
geotextiles, groundcover management,
orchard floor management

Summary. Natural (hay, wood chips, recycled paper pulp) and synthetic (polypropylene film and polyester fabric) mulches were compared with mechanical tillage and residual herbicides as orchard groundcover management systems (GMSS). In two New York orchards-the Clarke farm and Hudson Valley Lab (HVLGMSS were applied from 1990 to 1993 in 1.8-m-wide strips under newly planted apple (Malus domestica; 'Liberty', 'Empire', 'Freedom', and advanced numbered selections from the disease-resistant apple breeding program at Geneva, N.Y.) trees. GMS impacts on soil fertility, tree nutrition

${ }^{1}$ Department of Fruit and Vegetable Science, 118 Plant Science, Cornell University, Ithaca, NY 14853

${ }^{2}$ New York State Agricultural Experiment Station at Geneva, Hudson Valley Laboratory, Highland, NY 12528

Cornell University Department of Fruit and Vegetable Science paper no. 50. We gratefully ackwowledge the financial support of the U.S. Dept. of Agriculture programs in sustainable agriculture research and education and agriculture in concert with the environment in conducting this research. We also thank Steven Clarke, Elizabeth Ryan, and John A. Ray for providing orchards, advice, and assistance. Trade names are used in this manuscript solely for identification of material and do not imply any product endorsement. The cost of puhlishing this paper was defrayed in part by the payment of page charges. Under postal regulations, this paper therefore must be hereby marked advertisement solely to indicate this fact. 
and growth, yields, crop value, and vole (Microtus spp. ) populations were evaluated. After 3 years at the Clarke orchard, extractable $\mathrm{NO}_{3}, \mathrm{Mn}, \mathrm{Fe}, \mathrm{B}$, and $\mathrm{Zn}$ concentrations were greater in soil with herbicides than synthetic mulches; soil $\mathrm{K}$ and $\mathrm{P}$ concentrations were greater with herbicides and wood chips than synthetic mulches. At the HVL orchard, topsoil $\mathrm{NO}_{3}, \mathrm{~K}$, and $\mathrm{Mg}$ concentrations were greater with hay mulch than herbicides or other mulches; $\mathrm{Mg}$, $\mathrm{Fe}$, and $\mathrm{B}$ concentrations were lower in soil with wood chips than other GMSs. Soil organic matter content was not affected by GMS. Apple leaf N, K, Cu, and Zn concentrations were greater with herbicides, hay mulch, and polypropylene mulch than cultivation or recycled paper mulch at the HVL orchard during hot, dry Summer 1991. Despite transient differences among GMSS during the initial years, after 4 years of treatments there were no consistent GMS trends in cumulative tree growth or gross yields. The higher establishment and maintenance costs of several mulches were offset by their prolonged efficacy over successive years; crop market values from 1992 to 1994 were considerably greater for trees with polypropylene film, polyester fabric, and hay mulches than herbicides, cultivation, or other mulches. Voles caused more serious damage to trees in synthetic and hay mulches, despite the use of mesh trunk guards and rodenticide bait.

$\mathrm{M}$ ulches were an important method for or chard weed control and soil conservation before the development of herbicides. With recent efforts to reduce the agrichemical inputs in growing fruit, there has been increased interest in mulches as alternatives to herbicides. The number of mulches available has increased, and there are many different natural and synthetic materials. Polypropylene plastic films are now available in various colors and thicknesses and often are used in berry and vegetable crop production. Durable, permeable fabrics woven or spunbonded from polyesters and polypropylene have been developed for the landscaping industry, where they often are installed beneath crushed stone or tanbark to provide long-term weed suppression beneath trees, shrubs, and perennial groundcovers. Recycled biomass mulches consisting of wood chips, shredded newspapers, and municipal composts are becoming more available and affordable as solid-waste-management agencies try to minimize dumping in landfills. Traditional mulches such as hay or straw also continue to be popular with many home gardeners and some commercial fruit growers interested in controlling weeds and conserving or improving soil nutrient and water availability without resorting to herbicides. Considering these recent trends and developments, we conducted long-term field tests in two commercial orchards, comparing new and traditional mulches with herbicides and cultivation systems for weed control. In this report, we summarize the results from 4 years of these experiments.

Mulches maximize tree or vine growth, soil moisture retention, and the availability of essential plant nutrients in orchards and vineyards (Haynes, 1980; Mage, 1982; Ma-win and Stiles, 1994; Pool et al., 1990; Trzcinsky and Warzee, 1978). Home gardeners and organic fruit growers who cannot use synthetic herbicidal chemicals often rely on mulches or frequent tillage to suppress weeds (Natural Organic Farming Association-New York, 1994). However, mulch and its application costs are substantial (Smith, 1990), disposal of plastic mulches is increasingly problematic (Hofstetter, 1991), and the long-term costs and benefits of mulch systems need to be evaluated and compared with other soil management systems (Hogue and Neilsen, 1987; Merwin et al., 1994a; Pritts and Hancock, 1992). In 1989, we initiated several experiments to compare a variety of synthetic and natural mulches with conventional tillage or herbicide groundcover management systems (GMSS) in newly planted apple orchards at several sites in the Hudson Valley region of New York. The objectives of our field tests were to compare treatment costs and benefits, soil water and nutrient availability, tree establishment, and yield among the various weed-control systems.

\section{Materials and methods}

Test sites. We conducted GMS tests at five Hudson Valley orchards from 1990 to 1994, but this report focuses primarily on the results at two sites at which we were able to evaluate treatment costs, crop returns, and soil impacts most thoroughly-the Clarke orchard in Milton, N.Y., and Cornell
Univ.'s Hudson Valley Laboratory (HVL) orchard in Highland, N.Y. Previous orchards at both sites were removed before our plantings; the Clarke farm soil was a Chenango silt loam (Typic Dystrochrepts) and the HVL orchards were on a Bath gravelly silt loam (Typic Fragiochrepts).

At the Clarke farm, trees were planted in 100-m-long adjacent rows of different apple genotypes, and the GMSs were applied in 1.8-m-wide $\times 6$ m-long plots, each containing two trees. 'Empire,' Liberty,' and two numbered selections ('NY74828-12' and 'NY75414-1') from the-disease-resistant apple breeding program at the New York State Agricultural Experiment Station in Geneva (Merwin et al., 1994b) were grafted on 'Mark' rootstock and planted in a $3 \times 5$-m spacing in May 1990. At the HVL orchard, there were two separate, adjacent plantings (designated as the eastern and western blocks), and GMSS were applied in 1.8-m-wide $\times 5$-m-long main plots containing two apple genotypes as split-plot treatments. In the eastern block orchard, we planted 'Freedom' and a Geneva, N.Y., numbered selection ('NY73334-35') on M.9/MM.111 interstem rootstock at a $2.5 \times 3.7-\mathrm{m}$ spacing in May 1989. In the western block orchard, we planted two numbered selections ('NY66325-1 39' and 'NY7541 3-30') on the same rootstock, spacing, and date.

GMSs. In May 1990, we applied the following GMSS at the Clarke and HVL orchards:

1) Tank-mixed applications of oryzalin [4-(dipropyl-amino)-3,5-dinitrobenzene-sulfonamide, at 3.5 $\mathrm{kg}$ active ingredient (a.i.)/ha] plus glyphosate [N-(phosphono-me thyl) glycine, at $2 \mathrm{~kg}$ a.i./ha] herbicides in the year of planting, and in subsequent years simazine ( 6- chloro- $N, N^{\prime}$-diethyl - 1, 3, 5triazine-2,4 - diamine at $2.0 \mathrm{~kg}$ a.i./ha) plus glyphosate, applied mid-May (herbicides).

2) Soil cultivation to $6 \mathrm{~cm}$ deep at about monthly intervals, May to August annually (cultivation).

3) Mulch $10 \mathrm{~cm}$ deep with pulverized hardwood chips, not renewed after initial placement (wood chips).

4) Mulch 10-cm deep with haymostly timothy (Phleum pratense) and white clover (Trifolium repens) - renewed annually in May (hay mulch). 
5) Perforated black polypropylene (black PPM) mulch $0.13 \mathrm{~mm}$ thick (5 roil).

6) Nonperforated white polypropylene mulch $0.24 \mathrm{~mm}$ thick (white PM).

7) Agri-Tex polyester fabric (Agri-Tex Inc., Danbury, Corm. ).

8) Weed-Arrest spun-bound polyester fabric (Warren's Seed and Special Products Div., Davenport, Wash. ).

9) Belton-Sarlon Weed-Mat woven polypropylene fabric (Atlantic Construction Fabrics, Richmond, Vs.).

10) Circular 1-m-diameter bands of compressed recycled paper pulp placed around each tree (Weedcollar), with the rest of the plot seeded to sheep fescue grass (Festuca ovina 'Spartan'), mowed monthly.

GMSS were maintained or renewed as needed at both sites from 1990 to 1993; then the synthetic mulches were removed and glyphosate plus simazine herbicides were applied over the remaining natural mulches and other previous treatments in May 1994.

Design and statistical analysis. A different apple variety or numbered selection was planted in each of the four rows at the Clark farm, constituting four similar but independent experiments. Four GMSS were repli- cated in five complete blocks within each row. Three GMSS were common to all rows (Weed-mat, Agri-tex, and herbicides) and another GMS was unique to each row (hay mulch in the 'Empire' row, Weed-arrest in the 'Liberty' row, wood chips in the 'NY74828$12^{\prime}$ row, and Weed-collar in the 'NY75414-1' row). This test design was necessary to facilitate commercial operation of the Clarke orchard, but did not allow statistical comparisons among the four apple genotypes or testing of GMS $\times$ genotype interactions.

At the HVL plantings, the eastern and western blocks constituted two separate experiments, each with four blocked replications of five GMSS. The herbicide treatment was included in every experiment at both sites to provide a common check for comparison with the other GMSS. Analyses of variance and protected LSDS among treatment means were computed using the Supernova statistical program (Abacus Concepts, Berkeley, Calif.).

Trees were planted into cut openings or between the overlapping bands of synthetic mulches. Some handweeding was necessary around the 30cm-high mesh rodent guards surrounding each tree base, and the grassed drive lanes between tree rows were mowed at about 3-week intervals during the growing seasons. Trees were trained on poles to a French axe system as described by Forshey et al. (1992). During the 1991 and 1992 growing season, soil water potential was measured at $30 \mathrm{~cm}$ deep with tensiometers in each replicate at the Clarke orchard. At the beginning of August 1992, soil sample cores were removed from four opposite locations beneath the drip lines around trees in each plot (mulch covers were removed for sampling and then replaced afterward); cores were divided into 0 - to 10 - and 10- to 20$\mathrm{cm}$ profiles and then composite for nutrient analyses. Extractable soil nutrient concentrations, $\mathrm{pH}$, and organic matter (OM) content were analyzed using standard procedures (Greweling and Peech, 1965). In early August each year, 24 leaves were removed from different sides of all trees in each plot and combined to determine foliar concentrations of essential elements using standard procedures involving Kjeldahl digestion and argon-plasma spectroscopy. There were no irrigation facilities at any of the orchards, and $0.5 \mathrm{~kg}$ of $19 \mathrm{~N}-19 \mathrm{P}-19 \mathrm{~K}$ fertilizer was side-dressed around each tree annually in mid-March.

A rodent activity index (Byers, 1984) was assessed by placing apple slices in each plot and observing the proportion of slices that were gnawed or eaten by foraging rodents. Traps also were set in plots of each GMS in November 1991 and March 1992, and the proportion of traps in which

Table 1. Estimated materials and labor costs to establish and maintain 1.8-m-wide tree-vow strips of various groundcover management systems (GMSs) in an orchard planted at $3 \times 5 \mathrm{~m}$ spacing, and packout value for yields obtained in these GMSs from 1992 to 1994 at the Clarke and Hudson valley lab (HVL) orchards.

\begin{tabular}{|c|c|c|c|c|c|c|c|}
\hline \multirow[b]{2}{*}{ GMS $^{w}$} & \multirow{2}{*}{$\begin{array}{c}\text { Materials + labor } \\
\text { cost/application } \\
(\$ / \text { ha })\end{array}$} & \multirow{2}{*}{$\begin{array}{c}\text { Effective } \\
\text { longevity } \\
\text { (years) }\end{array}$} & \multirow{2}{*}{$\begin{array}{c}\text { Total GMS } \\
\text { costs }^{y} 1990-93 \\
\text { (\$/ha) }\end{array}$} & \multirow{2}{*}{$\begin{array}{c}\text { No. of } \\
\text { varieties in } \\
\text { GMS }\end{array}$} & \multirow{2}{*}{$\begin{array}{c}\text { Cumulative } \\
\text { mean yields } \\
(\mathrm{kg} / \text { tree })\end{array}$} & \multicolumn{2}{|c|}{$\begin{array}{c}\text { Packout value } \\
\text { 1992-94 }\end{array}$} \\
\hline & & & & & & $(\$ / \mathrm{bu})$ & (\$/ha) \\
\hline Cultivation & 70 & 0.1 & 840 & 2 & 78.9 & 3.48 & 9590 \\
\hline Hay mulch & $300-600$ & 1 & $1000-2400$ & 3 & 57.6 & 6.52 & 13120 \\
\hline Wood chips & $70-350$ и & 4 & $70-350$ & 3 & 55.0 & 5.66 & 10875 \\
\hline Weed-arrest & 4530 & 4 & 1130 & 1 & 50.8 & 7.45 & 13225 \\
\hline White PM & 225 & 2 & 450 & 2 & 89.6 & 5.83 & 18250 \\
\hline Black PPM & 200 & 2 & 400 & 2 & 78.7 & 3.61 & 9925 \\
\hline Weed-collar & 3430 & 2 & 6870 & 3 & 52.8 & 4.45 & 8210 \\
\hline
\end{tabular}

${ }^{\bar{z}}$ Crop values for all varieties in each GMS treatment based on yields per tree (1991 to 1994) and weighted average USDA market grade packouts, determined by sampling 10 fruit per tree in each GMS plot, using local market values for 'Empire' apple in 1993 and 1994 as price basis.

${ }^{\gamma}$ Total costs to establish, maintain, and renew (if necessary) each GMS from 1990 to 1993.

${ }^{x}$ Cumulative yields averaged for all varieties in each GMS at the Clarke and HVL orchards for 667/ha,

${ }^{y}$ Herbicides = applications of glyphosate plus simazine; cultivation = monthly rototillage; hay mulch = 10-cm layer of hay; wood chips = 10-cm layer of hardwood chips; Weed-mat, Agri-tex, and Weed -arrest =synthetic fabric mulches; white PM = white polypropylene mulch; Black PPM= black perforated polypropylene mulch; Weed-collar $=1$-m-wide ring of compressed recycled paper pulp.

${ }^{v}$ Lower estimate is for nonfeed waste hay, upper estimate is based on actual costs of purchased hay.

"Wood chips at test location were free for the hauling; an upper estimate is included for purchased wood chips. 
Table 2. Extractable soil concentrations of esential nutrients, $p H$, and organic matter (OM) at 0-10 and 10-20 cm deep after 3 years under different groundcover

\begin{tabular}{|c|c|c|c|c|c|c|c|c|c|c|c|c|}
\hline \multirow[b]{4}{*}{$\mathbf{G M S}^{\mathbf{z}}$} & \multicolumn{12}{|c|}{ Nutrient concn $\left(\mathrm{kg} \cdot \mathrm{ha}^{-1}\right)$} \\
\hline & \multicolumn{2}{|c|}{$\mathrm{NO}_{3}$} & \multicolumn{2}{|c|}{$\mathbf{K}$} & \multicolumn{2}{|c|}{$\mathbf{P}$} & \multicolumn{2}{|c|}{$\mathbf{C a}$} & \multicolumn{2}{|c|}{$\mathbf{M g}$} & \multicolumn{2}{|c|}{$\mathbf{M n}$} \\
\hline & & & & & & epth (cn) & & & & & & \\
\hline & $0-10$ & $10-20$ & $0-10$ & $10-20$ & $0-10$ & $10-20$ & $0-10$ & $10-20$ & $0-10$ & $10-20$ & $0-10$ & $10-20$ \\
\hline Weed-mat & $39^{y}$ & 13 & 280 & 257 & 7 & 3 & 2157 & 1670 & 342 & 272 & 29 & 27 \\
\hline Agri-tex & 19 & 12 & 282 & 280 & 8 & 5 & 2328 & 1946 & 359 & 302 & 29 & 29 \\
\hline Wood chips & 21 & 29 & 634 & 444 & 15 & 4 & 2195 & 1341 & 382 & 254 & 35 & 31 \\
\hline $\operatorname{LSD}^{\mathrm{w}}{ }_{(P<0.05)}$ & NS & 34 & 221 & NS & 6 & NS & NS & NS & NS & NS & 13 & 17 \\
\hline
\end{tabular}

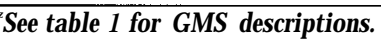

${ }^{y}$ Sampled 8 Aug. 1992.

${ }^{x}$ SE of mean for five observations per GMS treatment.

${ }^{w}$ Fisher's protected LSD for means at $\mathrm{P}<0.05$.

pine or meadow voles (Microtus pinetorum and ill pennsylvanicum) were caught during a 3-day observation period was recorded. Because of unbalanced sample sizes and apparent edge and site-specific effects in the vole counts at different orchards, we did not calculate mean separation statistics for these observations, but they are included here because the trends among GMSs were consistent at the three orchards and may be of practical interest to fruit growers.

Economic analyses. We estimated the establishment and maintenance costs for mulches and other GMSs by recording the materials costs incurred, the labor time required to establish and maintain each system, and prevailing local costs for equipment such as tractors and herbicide sprayers used in GMS treatments. We surveyed local growers' cost records for similar mulch systems in commercial fruit and vegetable farms, and adjusted our time and materials costs if they were too far out of line. All mulches were renewed or repaired as necessary to maintain coverage of the entire plot surface, so that our total cost estimates for GMSs would reflect their useful longevity in the orchards and maintenance or replacement costs during 4 years. The proportion of fruit grading into different U.S. Dept. of Agriculture (USDA) standard categories (extra fancy, fancy, utility, and culls) was determined in 1993 and 1994 by randomly sampling 10 fruit per tree for all the genotypes in all replications of each GMS. Crop market values were estimated for all genotypes using local farmgate prices for 'Empire' apples in the USDA grades, because no market prices had been established for the disease-resistant apple varieties and advanced selections.

\section{Results and discussion}

Tree growth and yield. Trees began to bear fruit in the third year at both orchards, and in 1992 and 1993 there were some differences in tree growth and yield among the GMSs at both sites (data not shown). At the Clarke farm in 1993, 'Empire' and 'NY-74828-12' trunk cross-sectional areas (TCSAs) were larger in hay and wood chips, respectively, than all other treatments, and 'NY74828-12' trees produced about 50\% more fruit (24.5 $\mathrm{kg}$ /tree) in wood chips than other treatments. At the HVL eastern block orchard in 1993, TCSAs were also greatest for the 'NY75413-30' trees in wood chips; otherwise, tree growth and yield were similar in all GMSs at both orchards in 1993.

At both sites in 1994, there were no significant differences in cumulative tree size or yield that could be attributed to GMS (data not shown). TCSAs at the Clarke orchard ranged from $13 \mathrm{~cm}^{2}$ ('NY75414-1' trees in Weed-mat) to $32 \mathrm{~cm}^{2}$ ( 'Empire' trees in hay); at the HVL orchard, TCSAs ranged from $22 \mathrm{~cm}^{2}$ ('NY66325-139' in Weed-mat plots) to $41 \mathrm{~cm}^{2}$ ('NY73334-35' with herbicides and 'NY75413-30' in hay). Although statistical analyses indicated that cumulative TCSA growth and yields from 1990 to 1994 were not significantly different among GMSs, there were substantial cost-benefit differences among treatments that would be important for commercial fruit growers (Table 1). The synthetic mulches differed greatly in cost and durabilitythe fabric mulches (Weed-mat, Agritex, and Weed-arrest) were much more durable than the polypropylene films (white PM and black PPM), which began to fray and disintegrate after 2 years. Establishment costs were highest for Weed-collar and Weed-arrest and lowest for the herbicide mixture and wood chips, which were available for the cost of hauling from a stockpile used by local power-utility tree crews.

When the longevity factor, renewal, and maintenance costs of each GMS were combined over 4 years of tests, Weed-mat, wood chips, and herbicides were the least expensive treatments (Table 1). Substantial differences in fruit size, color, blemishes, and preharvest drop among the eight apple genotypes and 10 GMS treatments resulted in a broad range of fruit packout values, from $\$ 3.48$ to $\$ 7.45 /$ $42 \mathrm{lb}$ ( $19 \mathrm{~kg}$ ) bushel. Cumulative crop market-value estimates based on yields and proportional packouts from 1992 to 1994 also varied greatly, from $\$ 8210$ to $\$ 18,250 /$ ha, assuming a planting density of 667 trees/ha. Some of the most expensive treatments (e.g., Weedcollar) were the least profitable, while trees in several low-cost mulches (white PM and wood chips) produced the most profitable crops. These observations indicate that GMSs may influence important factors other than tree growth and gross yields during orchard establishment, with major consequences for farm profitability.

Soi fertility impacts. At the Clarke orchard, soil nutrient availability differed little among GMSs after 3 years of treatments (Table 2). Nitrate concentrations were greater in the subsoil (10 to $20 \mathrm{~cm}$ deep) of herbicides than in synthetic mulch plots. Topsoil $\mathrm{K}$ and $\mathrm{P}$ were more available with herbicides and wood chips than under synthetic mulches. Topsoil and subsoil $\mathrm{Mn}, \mathrm{Fe}, \mathrm{B}$, and $\mathrm{Zn}$ concentrations were greater with herbicides than 
management systems (GMSs) at the Clarke orchard on a Ckenango gravelly silt-loam soil.

\begin{tabular}{|c|c|c|c|c|c|c|c|c|c|c|c|}
\hline \multicolumn{12}{|c|}{ Nutrient concn $\left(\mathrm{kg} \cdot \mathrm{ha}^{-1}\right)$} \\
\hline \multicolumn{2}{|c|}{$\mathrm{Fe}$} & \multicolumn{2}{|c|}{$\mathrm{Cu}$} & \multicolumn{2}{|c|}{$\mathrm{B}$} & \multicolumn{2}{|c|}{$\mathrm{Zn}$} & \multicolumn{2}{|c|}{$\mathrm{pH}$} & \multicolumn{2}{|c|}{$\mathrm{OM}(\%)$} \\
\hline & & & & Dep & $(\mathrm{cm})$ & & & & & & \\
\hline $0-10$ & $10-20$ & $0-10$ & $10-20$ & $0-10$ & $10-20$ & $0-10$ & $10-20$ & $0-10$ & $10-20$ & $0-10$ & $10-20$ \\
\hline 8 & 8 & 1.0 & 0.9 & 1.2 & 1.0 & 5.1 & 3.4 & 5.9 & 5.9 & 5.8 & 5.2 \\
\hline 8 & 8 & 1.1 & 1.1 & 1.3 & 1.0 & 6.7 & 4.9 & 6.1 & 6.0 & 5.2 & 5.8 \\
\hline 9 & 8 & 1.1 & 0.9 & 1.0 & 0.7 & 5,9 & 3.2 & 6.1 & 5.8 & 5.8 & 4.7 \\
\hline 10 & .10 & 1.3 & 1.1 & 1.8 & 1.4 & 8.4 & 6.4 & 5.6 & 5.3 & 5.2 & 6.3 \\
\hline 0.4 & 0.8 & 0.1 & 0.1 & 0.1 & 0.1 & 1.0 & 0.9 & 0.1 & 0.1 & 0.4 & 0.5 \\
\hline 1.3 & NS & NS & NS & 0.3 & 0.3 & NS & 2.3 & 0.3 & 0.3 & NS & NS \\
\hline
\end{tabular}

mulch, and soil $\mathrm{pH}$ was lower with herbicides than mulches. Soil OM content ranged from $4.7 \%$ to $5.8 \%$, but did not differ significantly among GMSs in 1992.

In the HVL eastern block orchard soil, different trends were observed after 3 years of treatments (Table 3). Nitrate and $K$ concentrations were greater in topsoil under hay mulch, and $\mathrm{Mg}$ concentrations were higher in the topsoil under hay mulch than with herbicides or Weed-mat. Topsoil Mn was less available under Weed-mat than other GMSs, and Fe was most available under hay mulch. Topsoil B concentrations were higher with herbicides and hay, intermediate under Weed-mat, and lowest under wood chips. Soil $\mathrm{pH}$ values were lowest under hay, but remained within optimal range of 6.6 to 6.9 in all GMSs. There were no significant differences in subsoil nutrient concentrations or soil OM content among these GMSs in 1992.

Soil water availability. Soil water availability (matric potential) under different GMSs varied substantially from year to year, and during a drought in July 1991 the soil was too dry for accurate measurements with tensiometers even at $30 \mathrm{~cm}$ deep. Average soil water availability at the Clarke orchard during cool, humid Summer 1992 was greatest with wood chips than other GMSs (repeated measures analysis; $P<0.01, \mathrm{n}=110$ ). Treatment $x$ date interactions occurred on many occasions, so these observations were interpreted graphically (Fig. 1). During May and June (days 130 to 175), the soil was usually drier with herbicides than mulches. In mid-summer (days 161 to 196), the soil was more moist with wood chips than herbicides. When a series of rainstorms occurred (days 198, 215, and 230) following a 2-week dry period, the soil with Agri-tex and Weed-mat appeared to dry out and rewet more quickly than with herbicides, which may indicate some wicking infiltration and evaporation of water from these fabrics. We attributed the relatively drier soil under Weed-mat and Agri-tex in late summer (days 246 to 259) to vigorous weed growth at the outer edges of those plots. The GMS impacts we observed on soil water infiltration and availability with mulches and herbi- cides parallel those reported by Glenn and Welker (1989) in a similar study. Soil moisture within the observed range of 5 to $95 \mathrm{kPa}$ was unlikely to cause drought stress for apple trees in any of our GMSs (Haise and Hagen, 1967); during a cool, wet summer such as 1992, there may have been greater risk of phytophthora root rot in saturated soil beneath mulched apple trees at a poorly drained site such as the Clarke farm (Merwin et al., 1992).

Leaf nutrient content. Summer weather patterns during these experiments were normal for the Hudson Valley in 1990 and 1994, unusually hot and dry in 1991 and 1993, and unusually cool and wet in 1992. The most notable GMS effects on tree nutrient uptake were observed in 1991 in the shallow soil at the HVL orchards (Table 4). In the western block planting, foliar $\mathrm{N}$ and $\mathrm{K}$ concentrations were lower in cultivation and Weedcollar plots. In the eastern block, foliar $\mathrm{K}$ concentrations were higher for trees with hay and wood chips than in the 0.9-m-wide Weed-mat plots; in the 1.8-m-wide Weed-mat plots, leaf $\mathrm{K}$ concentrations were greater but leaf $\mathrm{P}$

Table 3. Extractable soil concentrations of essential nutrients, $p H$, and soil organic matter (OM) content in topsoil after 3 years under different groundcover management systems (GMSs) at the Hudson Valley Lab eastern block planting in a Bath gravelly silt-loam soil.

\begin{tabular}{|c|c|c|c|c|c|c|c|c|c|c|c|c|}
\hline GMSs & $\mathrm{NO}_{3}$ & $\mathbf{K}$ & $\mathbf{P}$ & $\mathrm{Ca}$ & $\mathrm{Mg}$ & $\mathrm{Mn}$ & $\mathrm{Fe}$ & $\mathrm{Cu}$ & B & $\mathrm{Zn}$ & p H & OM $\quad(\%$ \\
\hline Weed-mat & $8^{\mathrm{y}}$ & 202 & 7.9 & 831 & 263 & 5.4 & 3.4 & 0.4 & 0.6 & 0.8 & 6.9 & 5.7 \\
\hline Wood chips & 4 & 292 & 10.4 & 917 & 197 & 6.7 & 2.9 & 0.4 & 0.4 & 0.5 & 6.8 & 6.3 \\
\hline Herbicides & 21 & 308 & 11.5 & 978 & 236 & 7.2 & 3.4 & 0.4 & 0.8 & 0.5 & 6.8 & 6.0 \\
\hline$S E M_{(n=4)}$ & 7 & 33 & 1.2 & 42 & 18 & 0.04 & 0.2 & 0.02 & 0.05 & 0.1 & 0.05 & 0.2 \\
\hline
\end{tabular}

${ }^{\bar{*}}$ See Table 1 for GMS descriptions.

${ }^{y}$ Sampled 8 Aug. 1992, at 0 to $10 \mathrm{~cm}$ deep.

${ }^{x}$ SE of mean for four observations per GMS.

${ }^{w}$ Fisher's protected LSD for means at $\mathrm{P}<0.05$. 


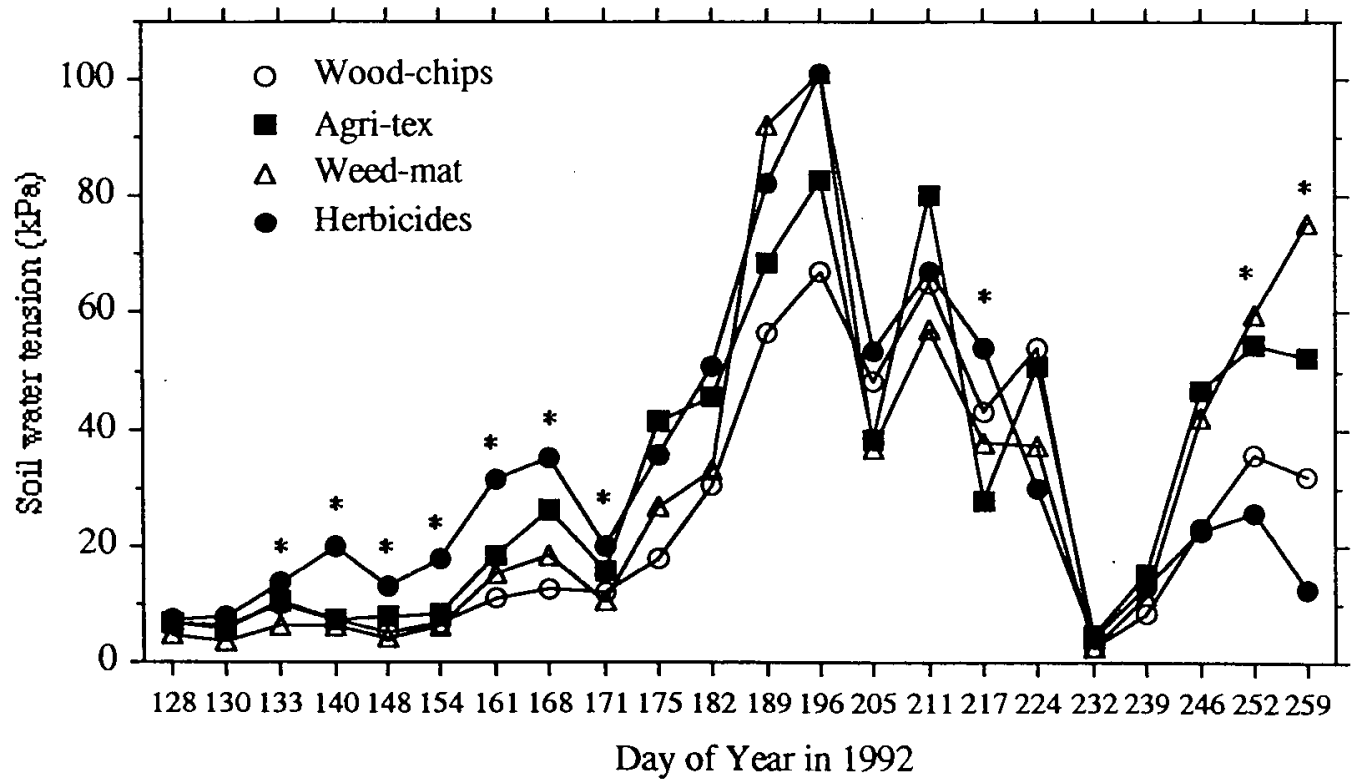

Fig. 1. Average soil water tension ( $\mathrm{kPa}$ ) at $30 \mathrm{~cm}$ deep in four groundcover management systems (GMSs) at the Clarke Orchard during Summer 1992. Sampling dates designated with asterisks ${ }^{*}$ ) when the means of five observations per treatment were significantly different $(\mathrm{P}<0.05)$.

concentrations were lower than in the 0.9-m-wide Weed-mat plots. Leaf $\mathrm{Cu}$ concentrations were greater for trees with wood chips, hay, and herbicides than with Weed-mat in the eastern block and with herbicides and white PM than with black PPM, cultivation, or Weed-collar at the adjacent western block. Leaf $\mathrm{Zn}$ concentrations were greater with herbicides than with other treatments at both blocks, and leaf concentrations well below the 14-ppm Zn-deficiency threshold reported by Shear and Faust ( 1980) were observed frequently in other GMSs at our test orchards throughout the Hudson Val leyin 1991 and 1992 (data not shown). The improved tree uptake of $\mathrm{Zn}$ with herbicides may bean important advantage of this GMS for orchards in New York.

The reduced foliar nutrient content with Weed-collar-where only 1 $\mathrm{m}^{2}$ of the plot surface was covered by mulch-and with cultivation and 0.8m-wide Weed-mat suggests that the area of weed suppression and efficacy of herbicides beneath trees became especially critical in the HVL orchards during the drought in 1991. Even under these conditions, however, the tree responses to each GMS were highly variable. For example, in the adjacent eastern and western blocks, leaf $\mathrm{N}, \mathrm{K}$, and $\mathrm{Zn}$ concentrations varied substantially in trees of similar size and crop load, for the same herbicide GMS, rootstock, and soil type (Table 4). Also, many foliar nutrient concentrations (N, K, Ca, Mg, $\mathrm{Cu}$, and $\mathrm{Zn}$ ) were below the ranges recommended for apple in New York (Stiles and Reid, 1991 ) in all of the treatments during 1991, regardless of GMS.

Other researchers have described substantial enhancement of soil water and nutrient availability under natural mulches compared with herbicides and mechanical tillage, but there have been very few studies comparing natural and synthetic mulches (Haynes, 1980; Hogue and Neilsen, 1987). We theorize that synthetic mulches may be similar to herbicides in their effects on soilseliminating surface plant residues, encreasing topsoil temperatures, and decreasing water infiltration rates, but not increasing soil nutrient availability as much as biomass mulches (Hogue

Table 4. Leaf nutrient concentrations (percentage or ppm, dry weight basis) of 'Freedom' and three numbered disease-resistant apple selections at the two Hudson Valley Lab plantings, sampled in different groundcover management systems (GMSs) on 7 Au.. 1991.

\begin{tabular}{|c|c|c|c|c|c|c|c|c|c|c|}
\hline \multirow[b]{2}{*}{ GMSs } & \multicolumn{10}{|c|}{ Leaf nutrient concn } \\
\hline & N (\%) & K (\%) & $\mathbf{P}(\%)$ & $\mathrm{Ca}(\%)$ & $\operatorname{Mg}(\%)$ & $\operatorname{Mn}(\mathrm{p}$ & e (ppm) & $\mathrm{Cu}(\mathrm{ppm})$ & B (ppm) & $\mathrm{Zn}$ (ppm) \\
\hline \multicolumn{11}{|c|}{ Western block } \\
\hline Cultivation & 1.8 & 0.9 & 0.13 & 0.9 & 0.30 & 73 & 101 & 5.3 & 27.3 & 11.7 \\
\hline Herbicides & 2.1 & 1.3 & 0.14 & 0.9 & 0.29 & 98 & 102 & 6.4 & 27.6 & 14.2 \\
\hline White PM & 2.0 & 1.2 & 0.15 & 0.9 & 0.29 & 76 & 87 & 5.8 & 27.9 & 12.5 \\
\hline Black PPM & 2.0 & 1.2 & 0.13 & 0.8 & 0.31 & 86 & 109 & 6.2 & 28.5 & 12.6 \\
\hline Weed-collar & 1.8 & 0.9 & 0.13 & 1.0 & 0.33 & 63 & 91 & 4.7 & 26.5 & 10.8 \\
\hline $\operatorname{SEM}_{(n=8)^{\gamma}}$ & 0.05 & 0.07 & 0.04 & 0.04 & 0.01 & 6 & 10 & 0.2 & 1.1 & 0.7 \\
\hline LSD $(\mathrm{P}<0.05)$ & 0.2 & 0.2 & NS & NS & NS & 16 & NS & 0.5 & NS & 1.8 \\
\hline \multicolumn{11}{|c|}{ Eastern block } \\
\hline Herbicides & 2.2 & 1.6 & 0.13 & 1.1 & 0.30 & 100 & 114 & 6.8 & 27.2 & 20.2 \\
\hline 0.9-m Weed-mat & 2.2 & 1.4 & 0.16 & 1.2 & 0.28 & 87 & 111 & 5.8 & 24.4 & 18.9 \\
\hline 1.8-m Weed-mat & 2.1 & 1.6 & 0.12 & 1.0 & 0.29 & 122 & 188 & 6.2 & 25.7 & 17.7 \\
\hline Hay mulch & 2.2 & 1.7 & 0.15 & 1.0 & 0.30 & 103 & 126 & 6.9 & 26.6 & 16.7 \\
\hline Wood chips & 2.2 & 1.6 & 0.16 & 1.1 & 0.30 & 119 & 130 & 6.5 & 26.1 & 17.2 \\
\hline $\operatorname{SEM}_{(\mathrm{n}=8)^{2}}$ & 0.06 & 0.06 & 0.01 & 0.06 & 0.01 & 11 & 13 & 0.2 & 0.8 & 1.2 \\
\hline LSD $\quad(P<0.05)$ & NS & 0.2 & 0.04 & NS & NS & NS & 38 & 0.5 & NS & NS \\
\hline
\end{tabular}

'See table 1 for GMS descriptions.

"Two apple genotypes were combined with four GMS replications when interaction and genotype effects were nonsignificant. 
Table 5. Vole activity, populations and injury to apple trees under various groundcover management systems (GMSs) at the Clarke and Hudson Valley lab (HVL) orchards in 1991 and 1992. Because of variable sample sizes, no inferential statistics are provided.

\begin{tabular}{|c|c|c|c|c|c|}
\hline \multirow[b]{2}{*}{ Orchard } & \multirow[b]{2}{*}{ GMS $^{\prime}$} & \multirow{2}{*}{$\begin{array}{c}\text { Activity index }(\%)^{y} \\
\text { Nov. 1991 }\end{array}$} & \multicolumn{2}{|c|}{ Trap captures $(\%)^{x}$} & \multirow{2}{*}{$\begin{array}{r}\text { Trees injured (\%) } \\
\text { Apr. 1990-July } 199 \\
\end{array}$} \\
\hline & & & Nov. 1991 & Mar. 1992 & \\
\hline \multirow[t]{7}{*}{ Clarke } & Herbicides & 0 & 0.0 & 0.0 & 0.0 \\
\hline & Weed-mat & 75 & 5.2 & 0.0 & 7.7 \\
\hline & Agri-tex & 60 & 6.7 & 5.0 & 5.0 \\
\hline & Weed-arrest & 40 & 5.7 & 3.4 & 0.0 \\
\hline & Weed-collar & 80 & 11.8 & 0.0 & 0.0 \\
\hline & Wood chips & 20 & 0.0 & 0.0 & 0.0 \\
\hline & Hay mulch & 0 & 0.0 & 0.0 & 10.0 \\
\hline \multirow[t]{7}{*}{ HVL blocks } & Herbicides & 0 & 0.0 & 0.0 & 0.0 \\
\hline & Weed-mat & 0 & 0.0 & 0.0 & 0.0 \\
\hline & White PM & 25 & 0.0 & 0.0 & 0.0 \\
\hline & Black PPM & 75 & 3.6 & 0.0 & 0.0 \\
\hline & Weed-collar & 75 & 10.7 & 0.0 & 0.0 \\
\hline & Wood chips & 0 & 0.0 & 0.0 & 0.0 \\
\hline & Hay mulch & 0 & 0.0 & 0.0 & 0.0 \\
\hline
\end{tabular}

${ }^{2}$ See table 1 for GMS descriptions.

${ }^{V}$ Activity index $=$ percentage of sites with apple slices chewed by unidentified rodents during 3 days of observations.

${ }^{x}$ Trap captures $=$ percentage of traps in each plot (4 to 20 plots/GMS) where voles were captured during 3 days of observations.

"Trees injured $=$ percentage of trees (sample size varying from 10 to 60 trees/GMS) with lower trunks damaged by vole feeding.

and Neilsen, 1987; Mage, 1982; Merwin et al., 1994). Natural mulches could affect soils differently, adding nutrients to the underlying soil by leaching, physical and chemical decomposition, and incorporation by earthworms and other animals. We also anticipate that there may be increased earthworm activity and soil or plant assimilation of the nutrients from mulches in our test orchards, because few or no fungicides and only four to six annual insecticide treatments were applied to these disease-resistant trees, and there have been reports of suppressed earthworm populations in orchards with frequent fungicide applications (Paoletti et al., 1991). However, after 3 years of mulching, there were no significant differences in soil OM content at either site, and soil availability of many essential nutrients was often similar with herbicides, hay, and wood chips or not consistently linked with GMS (Tables 2 and 3). Also, the higher yield market value in some of our synthetic and natural mulch compared with herbicides suggests a complex and indirect relationship between GMS effects on soil fertility and orchard profitability in these experiments (Table 1).

GMS effects on voles. Meadow and pine vole damage to trees was a serious problem, differing substantially among GMSs and from site to site in our tests (Table 5). We monitored vole populations and feeding activity from 1991 to 1992 and observed that bait feeding during 3-day periods varied from $0 \%$ to $80 \%$ of apple slices, and was generally highest under synthetic mulches at the Clarke orchard. Less feeding activity and tree damage occurred under the wood chips than other mulches, and none was observed where herbicides had been applied at either site. There were also consistently fewer vole depredation problems at the HVL than the Clarke orchard, and we attributed these differences to lower endemic populations and more vole predators at the latter site.

Voles are a serious pest in apple orchards throughout the United States, especially in orchards where dense groundcover provides ideal vole habitat (Byers, 1984). Despite preventive measures including mesh trunk guards, mounding crushed rock around rootstock shanks, continuous anticoagulant-bait feeding stations in each plot, and early winter broadcast applications of $\mathrm{Zn}$-phosphide baits, there were more voles and tree damage in mulched plots-especially the synthetic mulches-than herbicide-treated plots at the Clarke orchard. We did not include the potential damage to trees and yield losses to voles in our economic comparisons of the GMSs, because no data are available on the sublethal impacts of voles on fruit trees. We also noted that, at other Hudson Valley sites in our tests, there were few vole problems in trees under the same mulch, indicating that local vole population densities, natural predators, and other site-specific factors are important determinants of vole problems in orchards.

\section{Conclusions}

Some previous studies showed substantial benefits in tree growth, nutrition, yield, and soil conditions under orchard mulch systems and the advantages of mulches often are asserted in popular gardening magazines. However, because most mulches are more expensive to establish and maintain than herbicides, it is important to determine if the benefits of mulches compensate for their additional expenses. Our economic studies indicate that, for some fruit varieties, the increased crop value in mulched trees probably justifies the greater costs. Conversely, reduced fruit quality and lower packout crop values for trees in some herbicide systems may nullify the cost savings of these GMSs. The anticipated long-term benefits of increased soil fertility under mulches certainly are of some value, but were uncertain and inconsistent after 4 years in our field tests.

The lack of specialized equipment for establishing and maintaining synthetic mulches in orchards created some practical difficulties. For instance, despite burying the edges of mulch films and fabrics with soil, using landscape 
staples, and weighting down the mulch with stones, there were problems with the wind's blowing or tearing mulches during winter. Manging weeds at the edges of mulched strips was also problematic. During hand weeding, root proliferation from marginal weeds was evident beneath and within the synthetic fabric and biomass mulches. Mowers operated in the row middles sometimes snagged the synthetic mulches and dragged them out from under trees when we attempted to mow close to the edges of plots. When left unmowed, weeds along these edges grew vigorously, leaning into the tree canopies and spreading laterally over the mulch. Weeds also grew in the gaps around rodent guards at tree bases. In commercial orchards, these problems would likely require spot treatments with postemergence herbicides for acceptable weed control. Smallscale organic or home garden growers could rely on hand weeding within and around mulches, but the time and labor requirements would be considerable.

Researchers, extension workers, and farmers are responding to public and regulatory pressures for natural alternatives to agrichemical methods of weed control and crop nutrition. One alternative may be natural mulches derived from waste biomass and other renewable sources, which can often be obtained at low cost on-farm or from local recycling programs. Under these circumstances-and for organic fruit growers who cannot use synthetic herbicides-wood chips, shredded bark, or waste hay appear to be effective and affordable natural GMSs. However, synthetic and biomass mulches are likely to be prohibitively expensive for commercial fruit growers purchasing these materials off-farm, unless they produce fruit that consistently pack out into top price grades. Improvements in soil fertility and water conservation under mulches are potential long-term benefits that eventually may compensate for the greater establishment and maintenance costs and vole problems with these systems. However, for lowcost, high-volume fruit growers who market much of their crop in processing or utility grades, herbicide systems appear to be the most practical GMS.

\section{Literature Cited}

Byers, R.E. 1984. Control and management of vertebrate pests in deciduous orchards of the eastern United States, p. 253-285. In: J. Janick (cd. ). Horticultural reviews. vol. 6. AVI, Westport, Corm.

Forshey, C.G., D.C. Elfving, and R.L. Stebbins. 1992. Training and pruning apple and pear trees. Amer. Soc. Hort. Sci., Alexandria, Va.

Glenn, D.M. and W. V. Welker. 1989. Orchard soil management systems influence rainfall infiltration. J. Amer. Soc. Hort. Sci. 114:10-14.

Greweling, T. and M. Peech. 1965. Chemical soil tests. Cornell Univ. Agr. Expt. Sta., Ithaca, N.Y. Bul. no. 960.

Haise, H.R. and R.M. Hagan. 1967. Soil, plant, and evaporative measurements as criteria for scheduling irrigation, p. 137150. In: Hagan (cd.). Irrigation of agricultural lands. Amer. Soc. Agr., Madison, Wis.

Haynes, R.J. 1980. Influence of soil management practice on the orchard agroecosystem. Agroecosystems 6:3-32.

Hogue, E.J. and G.H. Neilsen. 1987. Orchard floor vegetation management, $\mathrm{p}$. 377430. In: J. Janick (cd. ). Horticultural reviews. vol. 9. AVI, Westport, Corm.

Hofstetter ${ }_{1}$ R. 1991. Plastic mulch, a blessing-And a curse. The New Farm 13(3):56-58.

Mage, F. 1982. Black plastic mulching, compared to other orchard soil management methods. Scientia Hort. 16:131136.

Merwin, I.A., W.F. Wilcox, and W. C. Stiles. 1992. Influence of orchard groundcover management on the development of phytophthora crown and root rots of apple. Plant Dis. 76: 199-205.

Merwin, I.A., W. C. Stiles, and H.M. van Es. 1994a. Orchard groundcover management impacts on soil physical properties. J. Amer. Soc. Hort. Sci. 119:216-222.

Merwin, I.A., S.K. Brown, D.R. Rosenberger, D.J. Cooley, and L.P. Berkett. 1994b. Scab-resistant apples for the northeastern United States: New prospects and old problems. Plant Dis. 78:4-9.

Merwin, I.A. and W. C. Stiles. 1994. Orchard groundcover management impacts on apple tree growth and productivity, and soil nutrient availability and uptake. J. Amer. Soc. Hort. Sci. 119:209-215.

Natural Organic Farming AssociationNew York. 1994. Organic farm certification standards and administrative procedures. Natural Organic Farming Assn.New York, Port Crane.

Paoletti, M.G., M.R. Favretto, B.R. Stinner, F.F. Purrington, and T.E. Bater. 1989. Invertebrates as bioindicators of soil use. Agr. Ecosys. Environ. 34:341-362.

Pool, R.M., R.M. Dunst, and A.M. Lakso. 1990. Comparison of sod, mulch, cultivation and herbicide floor management practices for grape production in nonirrigated vineyards. J. Amer. Soc. Hort. Sci. 115:872-877.

Pritts, M.P. and J.M. Hancock. 1992. Highbush blueberry production guide. NRAES, Ithaca, N.Y. Publ. no. 55.

Smith, P. 1990. Plastics of the '90s coming on strong. The Grower (Sept.): 10-11.

Schear, C.B. and M. Faust. 1980. Nutritional ranges in deciduous tree fruits and nuts, p. 142-163 In: J. Janick (cd.). Horticultural reviews. vol. 2. AVI, Westport, Conn.

Stiles, W. C. and W.S. Reid. 1991. Orchard nutrition management. Cornell Univ., Ithaca, N.Y. Info. Bul. 219.

Trscinshy, T. and A. Warzee. 1978. Influence d'une coverture plastique appliquee au pied des arbres sur le comportment, in 1976, de pommiers Cox's O.P. et Golden Delicious. Revue de L'Agriculture 36:89103. 